\title{
An Overview of Population Projections- Methodological Concepts, International Data Availability, and Use Cases
}

\author{
Patrizio Vanella ${ }^{1, *(\mathbb{D})}$, Philipp Deschermeier ${ }^{2,+}$ and Christina B. Wilke ${ }^{3,+}(\mathbb{D}$ \\ 1 Department of Epidemiology, Helmholtz Centre for Infection Research (HZI), 38124 Brunswick, Germany \\ 2 Institute for Housing and Environment (IWU), 64295 Darmstadt, Germany; p.deschermeier@iwu.de \\ Chair of Economics, FOM University of Applied Sciences, 28359 Bremen, Germany; christina.wilke@fom.de \\ * Correspondence: patrizio.vanella@helmholtz-hzi.de \\ + Equal contribution.
}

Received: 18 July 2020; Accepted: 31 August 2020; Published: 2 September 2020

check for updates

\begin{abstract}
Population projections serve various actors at subnational, national, and international levels as a quantitative basis for political and economic decision-making. Usually, the users are no experts in statistics or forecasting and therefore lack the methodological and demographic background to completely understand methods and limitations behind the projections they use to inform further analysis. Our contribution primarily targets that readership. Therefore, we give a brief overview of different approaches to population projection and discuss their respective advantages and disadvantages, alongside practical problems in population data and forecasting. Fundamental differences between deterministic and stochastic approaches are discussed, with special emphasis on the advantages of stochastic approaches. Next to selected projection data available to the public, we show central areas of application of population projections, with an emphasis on Germany.
\end{abstract}

Keywords: demographic trends; macroeconomic effects and forecasts; labor force and employment size and structure; forecasting and simulation: models and applications; stochasticity in forecasting; frequentist and Bayesian methods

\section{Population Projections-Concepts and Purpose}

Empirical population research has received many new impulses from the ongoing demographic transition. Available information on historical development, the status quo, as well as the future development of the population in a country or another spatial unit is essential for planning processes in politics and business administration. Forecasts of the size and structure of the future population are of great importance to be able to support planning processes in the best possible way with the generated data.

How the population of a country will develop in the future depends on three determinants: (I) fertility, (II) net migration, and (III) mortality. The projection of a population usually takes the ageand sex-specific population numbers at a given point in time as the starting population. Based on these, the population is extrapolated into the future using estimates of the future development of fertility, migration, and mortality. Usually, mortality and (net) migration forecasts are broken down by age and sex.

Our contribution introduces and discusses various basic concepts of population projections. In addition to the term "population projection", several other terms exist in the literature without always being clearly and uniformly defined. For example, the literature does not differentiate clearly between forecasts or predictions and projections or simulations. How can these terms be meaningfully distinguished from one another? 
A population projection shows how a population will develop in the future under certain assumptions regarding its size and structure. It thus has a conditional character, i.e., it is based on if-then statements. Since demographic processes are generally slow, their true extent often only becomes apparent after many years [1]. This applies without restriction to fertility and mortality as long-term processes of natural population development. In this context, the inertia of demographic processes is sometimes also referred to [2,3]. Migration processes, on the other hand, can also be influenced very suddenly by, e.g., politically and/or economically motivated structural breaks, and are thus much more difficult to assess. Population projections are usually of a long-term nature (usually over several decades), since planning based on them is also long-term, such as in infrastructural projects. Possibly problematic trends are to be identified at an early stage so that they can be counteracted if necessary. However, as the length of the projection horizon increases, so does the uncertainty, which further reinforces the hypothetical character of such population projections. Therefore, different scenarios are often calculated for better illustration of the range of possible developments or to highlight individual, realistic scenarios. Selected simulations can also be used to illustrate individual, stylized developments and their consequences, even if they are not expected to occur in this form in the future. For example, a simulation could be used to estimate how the population would develop if the total fertility rate reached a replacement-level of 2.1 children per woman [4].

A population forecast, on the other hand, makes statements about the expected future population development and claims to predict this development "correctly". Accordingly, the scientific literature repeatedly addresses potential sources of error in such forecasts [5] to further improve the quality of service for urban planners, for example. The time horizon of forecasts can be of a short, medium or long-term nature, although the uncertainty of forecasts naturally increases with a longer forecast horizon [6,7]. Uncertainties in population forecasts are therefore often quantified in terms of the probabilities of occurrence of the possible development paths [7].

The presented distinction between projections or simulations on the one hand and predictions or forecasts on the other hand is of importance to avoid misinterpretation of the results by the addressees of the simulation results [8]. Or as the demographer Nathan Keyfitz already put it in the 1970s: "A demographer makes a projection, and his reader uses it as a forecast" [9]. In fact, every forecast in the form of a simulation always represents a projection at the same time, since a population projection is always made in any case. However, the reverse conclusion does not apply-a projection is not automatically a forecast, since it does not necessarily claim to be a correct prediction.

Our contribution aims at giving an overview of the most important distinctions and discusses methodological approaches common in population projections with their respective advantages and disadvantages. We aim at an audience not specialized in demography but rather with basic knowledge of statistics or specifically forecasting, who are interested in how population forecasts, as the basis of many further forecast applications (see Section 4), can be done. Therefore, we try to cover a rather large topic in a nutshell and give literature tips for further reading on the notions mentioned in our paper.

In the following, we first explain some basic conceptual approaches to the methodology of population projections (Section 2). We intend to give a short overview and introduction to approaches to population projections and their value as an input for further planning in other fields, such as economics, to readerships less familiar with population projections. Therefore, we do not give a full literature review; the contribution hence does not claim completeness. For broader literature reviews on methodological approaches see, e.g., [10] or [11]. Some newer approaches are mentioned explicitly in the next two sections, however. We then present some selected data sources at the global, European, national, and subnational levels (Section 3). Section 4 provides an insight into the various fields of application of such population projections. Our goal is to give a broad, yet not complete, overview of a variety of topics in forecasting, for which population forecasts are utterly important, if not indispensable, as underlying data. This serves as a motivation even for those not being from the field of demography but other fields connected to the demographic development. These should gain a 
deeper understanding of how population forecasts, which they use as auxiliary data, are conducted and be aware of the limitations of the specific approaches used. Readers only interested in the mechanics of demographic forecasting or data availability might feel free to skip that section. The article concludes with a summary.

\section{Conceptual Approaches}

Historical approaches to population projections were based on mathematical growth models. For example, arithmetic or geometric growth of the population or doubling periods were assumed for the population size [11,12]. Later approaches assumed a parametric growth of the total population [13].

The currently most commonly used method for population projections is the so-called cohort component method (CCM) [7,11], which simulates the demographic components fertility, migration, and mortality separately and then merges these results into a simulation of the future population. This can be illustrated by a simple example.

Let $P_{t-1}$ be the population at the end of period $t-1$. The population changes according to the CCM in period $t$ by adding the births $B_{t}$ and the net migration $M_{t}$, and subtracting the deaths $D_{t}$ :

$$
P_{t}=P_{t-1}+B_{t}+M_{t}-D_{t}
$$

Contrary to common misconceptions in the literature, the CCM goes back at least to the Census Bureau of England and Wales, which used it to project the population of England and Wales [14]. Significant further developments were achieved by Cannan [15] and Whelpton [16], among others. The CCM is merely a framework to combine the various components. The simulation methods applied to the individual components can be easily adapted to the knowledge of the modelers and the quality and depth of the available information. The components are usually predicted differentiated by age and sex. Further distinctions can also be made. For example, Fuchs et al. [17] distinguish the population not only by gender and age but also by nationals and foreigners. The demographic components are highly dependent on the demographic structure of the underlying population. For instance, the birth numbers are relatively high, if a large share of the females is in the age group 25-35 years [4]. A very old population is associated with many deaths [12]. Migration is relatively frequent among small children and young adults due to labor and study reasons $[18,19]$. Therefore, population projections are commonly done via demographic rates instead of crude numbers $[3,4,7,17,20-24]$. This is difficult in the case of immigration however, see, e.g., [7] on that. An extension of (1) could be written as

$$
P_{t, a, g}=\left\{\begin{array}{c}
P_{t-1, a-1, g}+M_{t, a, g}-D_{t, a, g} \text { for } a>0 \\
B_{t, g}+M_{t, a, g}-D_{t, a, g} \text { for } a=0
\end{array},\right.
$$

for age $a$ and sex $g$. Many researchers use the end-of-year population of the previous year, combined with age-specific rates, as the basis for their population update [12]. Vanella and Deschermeier propose to use the end-of-year population of the current population as the basis of the projection of the deaths to include migrant mortality in the model. Furthermore, they suggest to take the mean female population as the basis for the birth forecasts, which allows for consideration of migrant fertility and mortality in the birth forecast [7]. We could formulate the projection formula following the Vanella-Deschermeier algorithm as

$$
P_{t, a, g}=\left\{\begin{array}{c}
s_{t, a, g}\left(P_{t-1, a-1, g}+M_{t, a, g}\right) \text { for } a>0 \\
s_{t, 0, g}\left[\rho_{t, g} \sum_{x=r}^{R} \varphi_{t, x} \frac{P_{t-1, x-1, f}+s_{t, x, f}\left(P_{t-1, x-1, f}+M_{t, x, f}\right)}{2}+M_{t, 0, g}\right] \text { for } a=0
\end{array},\right.
$$

with

- $s_{t, a, g}$ being the survival rate of persons aged $a$ years at the end of year $t$ of sex $g$,

- $\rho_{t, g}$ being the share of new-born of sex $g$ in year $t$, 
- $\varphi_{t, x}$ being the fertility rate of females aged $x$ years at the end of year $t$.

An algebraic representation of that process, assuming age 13 to 54 as female reproductive phase, is $[7,12]$

$$
\begin{gathered}
\left(\begin{array}{c}
P_{t, 0, m} \\
P_{t, 1, m} \\
\vdots \\
P_{t, 0, f} \\
P_{t, 1, f} \\
\vdots
\end{array}\right)=\left(\begin{array}{cccccc}
s_{t, 0, m} & 0 & \ldots & & \\
0 & s_{t, 1, m} & 0 & \ldots & \ldots \\
\vdots & 0 & \ddots & & & \\
& \vdots & & s_{t, 0, f} & 0 & \ldots \\
& \vdots & & 0 & s_{t, 1, f} & 0 \\
\vdots & 0 & \ddots
\end{array}\right)\left\{\left(\begin{array}{c}
0 \\
P_{t-1,0, m} \\
\vdots \\
0 \\
P_{t-1,0, f} \\
\vdots
\end{array}\right)+\left(\begin{array}{c}
\rho_{t, m} \\
0 \\
\vdots \\
\rho_{t, f} \\
0 \\
\vdots
\end{array}\right)\right. \\
\\
\times\left(\begin{array}{c}
\frac{\left[P_{t-1,12, f}+s_{t, 13, f}\left(P_{t-1,12, f}+M_{t, 13, f}\right)\right]}{2} \\
\frac{\left[P_{t-1,13, f}+s_{t, 14, f}\left(P_{t-1,13, f}+M_{t, 14, f}\right)\right]}{2} \\
\vdots \\
\frac{\left[P_{t-1,53, f}+s_{t, 54, f}\left(P_{t-1,53, f}+M_{t, 5, f}\right)\right]}{2}
\end{array}\right)+\left(\begin{array}{c}
\varphi_{t, 14} \\
M_{t, 0, m} \\
M_{t, 1, m} \\
\vdots \\
M_{t, 0, f} \\
M_{t, 1, f} \\
\vdots
\end{array}\right)
\end{gathered}
$$

Projection methods can be fundamentally divided into deterministic and stochastic approaches. Both approaches have advantages and disadvantages, which modelers should consider when choosing a specific approach.

The more common deterministic population projections estimate the future population development by setting the model parameters in one or more scenarios. Deterministic models are relatively easy to use since they do not require large capacities for computation and can be implemented quickly. Furthermore, complex relationships with many parameters can be easily represented and calculated. Furthermore, changes in the parameters can be integrated well; therefore, sensitivity analyses can be carried out well when the model assumptions are varied (see, for example, [25] for sensitivity analyses on the statutory pension insurance or [26] for comparable studies on the statutory long-term care insurance in Germany). Deterministic approaches are simple to implement and easy for nonexperts to understand [27].

However, deterministic models have several limitations. Firstly, the nature of population processes is not deterministic but probabilistic [11,28]. Secondly, deterministic approaches make rather rigid assumptions about future development. From a statistical perspective, the trajectories resulting from individual scenarios have very low individual probabilities of occurrence [3,28]. Thirdly, the number of scenarios considered is naturally very limited [7], which means that the future risk is not adequately reflected [29]. Fourthly, the identified possible future paths are generally not quantified with probabilities of occurrence at all. Fifthly, these trajectories are often based on the assessments of a limited number of experts. However, these assessments tend to be subjective, which makes them susceptible to bias based on the personal opinions of the respondents. Even proven experts tend to perform worse with their value-based forecasts than forecasts based on a stable statistical foundation $[7,30]$. Even if those experts make very good assessments, they generally find it difficult to quantify their identified scenarios with probabilities [31].

Stochastic approaches differ significantly from deterministic approaches in their basic philosophy. In contrast to deterministic models, the model parameters are not fixed, but are understood as random variables. While a deterministic projection model assumes constant values for $G_{t}, M_{t}$, and $S_{t}$ in the context of specific scenarios, the stochastic approach interprets these variables as probabilistic:

$$
\widetilde{B}_{t}=\widetilde{B}_{t-1}+\widetilde{G}_{t}+\widetilde{M}_{t}-\widetilde{S}_{t}
$$


where the tilde above the variables indicates that they are random. Instead of assuming a fixed value, this approach assigns specific distributions to the variables [11,28].

Even among stochastic forecasting approaches, there is in principle a large number of possibilities; the most significant distinction is between frequentist and Bayesian approaches. Frequentist approaches rely almost exclusively on statistical information and are therefore purely quantitative in nature. Frequentists rely on the quality and completeness of the available data. This philosophy has the advantage of being very objective. Only time series data are fed into the model, such that the forecasts are extrapolated from historical developments. The only disputed issue is whether historical developments can be seen as representative of future developments. Vanella and Deschermeier [4] show, however, using the example of the total fertility rate, that a stochastic frequentist approach based on good data can achieve better forecasts than qualitative approaches do. This, however, does not always apply and depends very much on the variable and the available data. Population forecasts according to the CCM have a high degree of dimensionality due to the differentiation in fertility, migration, and mortality in combination with the aforementioned differentiation according to age, sex, and possible further subdivisions [7]. This can be countered very well with quantitative methods using principal component analysis (PCA). PCA is an established method, which applies an orthogonal transformation to the original set of time series, rendering linear combinations of these. E.g., assume we want to forecast 35 time series of age-specific fertility rates $\varphi_{1, \ldots, 35}$ until some period $\tau$. Applying PCA, we derive time series of 35 principal components $\Pi_{1, \ldots, 35}$. The $i^{\text {th }}$ principal component is derived as

$$
\Pi_{i}=\sum_{j=1}^{35} e_{i, j} \varphi_{j},
$$

with $e_{i, j}$ being the loading of $\varphi_{j}$ on $\Pi_{i}$. The principal components are derived iteratively by singular value decomposition. E.g., [32] gives a mathematical introduction to PCA; more applied recourses, among others, can be found in [33] or [34], the latter with special emphasis on forecasting in demography. PCA is the method of choice for dealing with high dimensional data and cross-correlations among the time series. Bozik and Bell [20] proposed merging PCA with autoregressive integrated moving average (ARIMA) models, which had been developed by Box and Jenkins [6], for fertility forecasting. This approach was then simplified and popularized by Lee and Carter for mortality forecasting [22]. Modern approaches apply this method to migration forecasting as well [17,35]. Nevertheless, it is essential not to blindly trust the forecast results but to also check their qualitative plausibility [34].

Bayesian approaches follow a mixed approach between qualitative and quantitative forecasting. The basic idea here is to assume an a priori distribution for a certain parameter that represents prior knowledge of the variable in question. This distribution can be varied in such a way that the a priori information or the belief in future developments is weighted more or less. At the same time, the assumed uncertainty about the parameter can be represented by choosing the distribution. If, for example, the modelers believe that net migration figures in ten years are highly likely to reach 200,000 people, the modelers could choose a very narrow (i.e., low variance) symmetrical distribution with an expected value of 200,000, e.g.,

$$
M_{t+10} \sim \mathcal{N}\left(200,000 ; 10,000^{2}\right) .
$$

If, however, the modelers are very uncertain about future developments, a very broad and deep, platycurtic distribution could be chosen so that the uncertainty would be included by assuming a high variance. A standard approach in univariate Bayesian models is to assume a uniform prior (Often called an uninformative prior in this context) [36]. 
For instance, in the migration example, the modeler might be unsure about the magnitude of net migration in ten years but expects a net migration of 200,000 on average, with extreme values of $1,000,000$ and $-600,000$. The prior would then be

$$
M_{t+10} \sim \mathcal{U}(-600,000 ; 1000,000)
$$

being associated with a prior density function (with $x=1$ being 1000 net migrants)

$$
m_{1}(x)=\frac{1}{1000+600}=\frac{1}{1600}, x \in[-600 ; 1000] .
$$

This example illustrates how Bayesian approaches have the advantage of comparative flexibility and the ability to incorporate various sources of information (such as auxiliary data from surveys, other studies, or even expert knowledge) into the analysis [3]. With the Bayesian approach, additional information is then successively fed into the model. This is called Bayesian updating, which converts the prior distribution into a posterior distribution [37]. We explain this process by a simple deviation from our migration example. Let us assume one year has passed since the initial forecast. The modeler has observed the migration development in $t+1$ and based on that changes their original assessment. Based on the new evidence, they believe the net migration will probably be within the range $-300,000$ and 1,000,0000, with equal probability. Within the Bayesian updating, the prior is multiplied with the new likelihood function. The sum of these products is then divided by a normalizing constant, which ensures an area of exactly one under the new function, making it a valid posterior density [37]:

$$
m_{2}\left(x \mid m_{1}\right)=\frac{m_{1}(x) * l(x)}{\int m_{1}(\xi) * l(\xi) d \xi^{\prime}}
$$

which in this example results in

$$
m_{2}\left(x \mid m_{1}\right)=\frac{\frac{1}{1600} * \frac{1}{1300}}{\int_{-300}^{1000} \frac{1}{1600} * \frac{1}{1300} d \xi}, x \in[-300 ; 1000] .
$$

Multivariate problems may then be generalized by using a Dirichlet distribution as a prior. We will not go deeper into this, as this would exceed the scope of this contribution.

Bayesian approaches can be advantageous in case of a weak database, for example in case of short time series or erroneous data. In the demographic context, for example, it may be appropriate to produce Bayesian projections for international migration [3], where for various reasons the data are very error-prone and representative time series are short [35]. Bayesian methods might be applied to mortality forecasting of the elderly, as the population figures in this age group are erroneous. This is also primarily due to errors in the migration data. In this age group, in which the population figures are no longer as high, this sometimes results in a major bias of the mortality risks [7,35]. We will go deeper into the notion of practical data problems in forecasting in Section 5.

However, it should be borne in mind that a Bayesian approach involves a great deal of subjectivity, as this brief overview makes clear [7]. The questions of which information to include a priori in the models, how it should be weighted (i.e., how strong further information should influence the parameters stated in the prior distribution), and what distribution should be assumed, must be clarified. Besides, the calculations that these models require cannot be implemented trivially and are therefore not suitable for less experienced modelers. The simulations are carried out in the form of the relatively complex Markov Chain Monte Carlo (MCMC) Simulation [37], which requires considerable capacity and time for computation in the case of complex population processes. It is also quite complex and less feasible to integrate multiple variables in the analysis, and especially the accompanying cross-correlations, in Bayesian models. 
This section should only give a small insight into the variety of methods used in population forecasts and therefore does not claim to be complete. For a larger overview of possible approaches, the reader might refer to the excellent, but slightly outdated, compilations by Booth [10] and Bohk [11].

\section{International Population Data}

Official statistical offices mostly rely on the CCM for their projections of future population trends; commonly, these calculations are deterministic. The detail and purpose of these projections vary with the chosen spatial level. While global projections tend to focus on global development trends [38], national calculations usually aim to quantify demographic (sub-)processes and their effects [39]. Small-area population projections, on the other hand, tend to provide selected key data for the design of spatial and settlement structures and thus have a strong link to regional and local politics [40]. In the following, some selected population projections at global, European, national, and subnational levels are briefly presented.

\subsection{Global and Continental Population Projections}

The United Nations Population Division (UNPD) has been producing demographic estimates and projections for all countries and territories of the world on an annual basis for more than 25 years. The projection currently available is from the year 2019 [41,42]. The historical demographic development for the period from 1950 up to now is estimated first and then the future population development up to the year 2100 is calculated. The estimates are based on all available data sources on population, fertility, mortality, and international migration for 235 different countries and territories, which make up the total population of the world.

Methodologically, the UNPD uses the above-mentioned approach of the CCM to maintain internal consistency by age and sex over time for the historical estimate from 1950 onwards. This method is also used for the projections up to 2100 to be able to project the future population using different demographic assumptions regarding the individual components. In estimating future fertility and mortality levels, probabilistic methods based on Raftery et al.'s Bayesian Hierarchical Model [43-46] are used to incorporate the uncertainty of the projections based on available data and qualitative assessments by national experts into the analysis. First, summary statistics are projected (the total fertility rate for fertility, life expectancy for mortality), from which age-specific projections are derived assuming age schedules. The mean projection corresponds to the median of several thousand trajectories of each demographic component. It takes into account both the experience of individual countries and the uncertainty of future developments based on the experience of other countries under similar conditions. In addition to the middle variant, several other variants are published to show the sensitivity of the projections to changes in the underlying assumptions and to be able to analyze the effects of alternative future scenarios of population development. So-called credible intervals reflect the dispersion of results over the projected trajectories [47].

However, the UN projections are only partially stochastic; international migration is deterministically determined in the model. Although it is highly relevant for the projections of population development in the individual countries, migration is only of minor importance at the global level of world population to the extent that it influences global fertility or mortality [48]. The current projections from 2019 show that, according to the UN, the world population is expected to grow with a probability of 95 percent to about 10 to 20 billion by 2050. Thereafter, due to declining fertility, the world population will tend to decline slightly in terms of volume, to 9-13 billion people in 2100. At this global level, uncertainty about the size of the future world population is largely caused by uncertainty about projected fertility - and not, as is generally the case at a smaller scale, by uncertainty about future net migration [49]. After all, the actual global international net migration sums to zero. The UN projections can be downloaded from the website of the UNPD [50].

Another example of an international projection is that of Eurostat for the European Union (EU) and the European Free Trade Association countries Iceland, Liechtenstein, Norway, and Switzerland. 
Eurostat's projections are also based on the CCM [51], but in contrast to the UN's, they are purely deterministic. The most recent population projection published by Eurostat is from 2020 [52]. It contains a base variant and four other variants and shows the development of the population, starting with the baseline year 2019. In the basic variant, the population of the EU-27 will shrink by almost 7 percent, i.e., by around 30 million people, by 2100 . In the medium term, however, it is expected that the population will continue to increase until 2025, up to a peak of about 449 million people, before gradually declining to 416 million people in 2100 [53]. Eurostat's projections are provided by country, sex, and age at their database [53].

\subsection{National Population Projections}

Many national statistical offices provide country-level population projections for public use. Exemplarily, two of them are presented here, which follow very different methodologies. For Germany, the Federal Statistical Office Destatis regularly publishes the so-called "Coordinated Population Projections" in co-operation with the statistical offices of the 16 federal states. The current 14th version was published in 2019 [39]. It is based on the population in 2018 and extends to 2060, which means that the projection period here is significantly shorter than in the population projections of the UNPD or Eurostat. Destatis' projections are purely deterministic. To be able to adequately reflect possible future developments of the demographic components, three different assumptions on the development of fertility, net migration, and mortality were made in each case (high, medium, low), from which nine main variants and 12 further variants are derived. These shall illustrate the range of possible future developments. Destatis offers projections of the population by age and sex or projections of household sizes on their online platform GENESIS-Online [54].

Italy, as a contrast, approaches its projections quite differently. The national statistical office Istat performs expert-based stochastic projections with a two-step survey among Italian experts in the field of demography, based on Billari et al. [55]. In the first step, the respondents are asked to give assessments of their expected mean number of children per female, the male and female life expectancy, the emigration number, and immigration number at the end of the first period, the year 2040. For all variables, the respondents are asked to add a high variant, corresponding to the 90th percentile. For the endpoint of the second period, the year 2065, the experts are asked for conditional projections of the variables under the assumption, that their estimated values for 2040 would take place. Assuming bivariate Gaussian distributions for all couples of variables for the years 2040 and 2065, these are simulated 3000 times by MCMC, leading to trajectories of annual age- and sex-specific population numbers based on assumed age schedules [56]. The first probabilistic projection was conducted in 2017, based on the survey among 24 experts. Its results can be accessed by different quantiles at Istat's database [57]. The second wave of the survey was conducted in 2019; however, the projection based on that was not yet published at the time this contribution was written.

\subsection{Subnational Population Projections}

Many statistical offices publish small-area projections for federal states, regions, districts, or even municipalities. Two examples from Germany and Italy are introduced shortly. This is certainly only an extremely small subset of the provided data globally, but our aim here is to give a short impression of what is done on subnational levels.

For instance, at the subnational level, the German Federal Institute for Research on Building, Urban Affairs and Spatial Development (BBSR) projects the future development of the population, including the number of households and the employment level, based on assumptions regarding the size of households and the age structure of the population in combination with the assumed labor force participation rates. The current projection is based on the data for the year 2012, thus taking into account the results of the 2011 census and extends to the year 2035 [58]. The projection by Destatis is taken into account in different ways: while some federal states adopt the results unchanged, others modify the results according to regional circumstances or calculate their own projections. After the data at the 
national and federal state level are fixed, they are then distributed to the smaller level using population shares. This also applies to the household and labor force figures generated based on the population projections [59].

For Italy, Istat's regional projection is done semi-stochastically alongside the national projection. Using a top-down first projection step, the simulated summary statistics presented in 3.1 are interpreted as weighted sums of the corresponding regions' statistics for the 3000 trajectories. From there, the numbers of deaths, births, and internal migrants are derived, which are then cumulated bottom-up to receive the projections on the national level [56]. Therefore, Istat is making sure that the projections on the regional and national levels are coherent, and this on an at least partially stochastic level.

\section{Selected Areas of Application of Population Projections}

This section highlights selected areas of application of population projections with a focus on Germany. The case of Germany is relevant as its demographic outlook changed in recent years. For example, the freedom of movement for workers in the EU since 2011 or a significant increase in births resulted in population growth. Germany is the most populous country in Europe and has witnessed a paradigm shift recently. After decades of assumed shrinkage of the population due to assumed constant fertility and decreasing migration (see, e.g., $[25,60,61]$ ), recent studies forecast an increase of the population over the next years, before a decrease might take place $[7,17,62,63]$. This leads to a high demand for new forecasts in several fields. Therefore, Germany appears to be an interesting case study, which is why the focus of this section is on Germany, although the examples apply to other countries as well. Against this background, many new forecasts and applications have emerged.

Population projections serve as a quantitative basis for a variety of different applications and actors. In the coming decades, society is facing a radical macroeconomic structural change that will affect all important markets: the labor market in industrialized countries lacks young workers [17], product markets must adapt to structurally changed consumer wishes and increasing longevity $[24,64,65]$, the housing market has to align the housing stock with the requirements and housing desires of older people [66], and savings behavior and the demand for investments on the capital market are transforming $[67,68]$. In addition to the mentioned labor market trends, the social insurance systems face a greater financial burden on the expenditure side due to rising population figures in the higher and more vulnerable age groups [25,29]. Population projections thus form an important basis for many thematic fields. In this section, particularly relevant exemplary applications are highlighted, with no claim of completeness.

\subsection{Labor Market}

Demographic aging will have a strong impact on the labor market when the baby boomer generation retires and the ratio of senior citizens to people of working age will shift in favor of older people. Accordingly, the labor market will have to adapt to the emerging changes. A central area of application is therefore labor supply forecasts, which are based on population forecasts with assumptions on labor force participation [17,63,69]. Demographic transition in particular, along with other influences such as globalization, poses growing challenges for companies and their human resources management. The availability of qualified workers is increasingly becoming a decisive determinant for the future viability of individual companies as well as entire sectors and the competitiveness of entire economic areas [63,70].

The need for information on future demographic development is correspondingly high and thus represents a basic prerequisite for estimating future labor market development at a small-area level. Planning requires knowledge of the future labor supply, since the emerging demographic change is leading to a decline in the population of younger people $[7,17,63]$. Regions are therefore increasingly competing for young and well-educated workers [71] because demographic development is unevenly distributed both at the regional level and across small areas and will have an unbalanced impact on individual regional labor markets [72]. The result will be competition for highly skilled 
workers which-with major regional differences-is already noticeable in some sectors of the economy [73]. The need for small-area population forecasts and labor market forecasts based on them is correspondingly high.

\subsection{Housing Market}

The labor market is closely intertwined with the housing market at the regional level. Large cities play a key economic role in regional development, as they provide more than one-third of all jobs [1,74]. However, a regional labor market is not exclusively characterized by the labor market center, but also by the surrounding area, which is mostly used as a residential location and from which workers commute to the centers [75]. Against the background of tight housing markets in large cities and university towns, a large number of projections of future housing requirements are currently being conducted globally [76-78], which are based on population projections. Housing demand analyses are important because the planning horizon for the development of the housing stock is long-term. Knowledge of future demand for housing is therefore extremely important in the development of new construction projects [79].

\subsection{Economic Growth}

At the national level, housing demand analyses and labor market projections serve as a quantitative basis for policy decisions. Thus, population projections and the future budget development derived from them form the basis for determining building requirements, which in turn make the existing need for action clear to politicians. In the case of projections of the labor supply side, projections of the demand for labor allow conclusions to be drawn about the development of the economy as a whole. For example, Grömling [80] shows, based on Deschermeier's population forecast [81] and Schäfer's projections of labor supply and labor demand [82], that the potential growth of the German economy up to 2035 will weaken noticeably due to the decline in the working population as a result of the aging of the society, despite increasing labor market participation. On such a basis, Bardt and Klös [83] formulated recommendations to various policy areas for securing prosperity. In general, the future size and structure of the population have a significant impact on the labor market, consumption, health, and in conclusion the productivity of an economy. The so-called demographic dividend is therefore an important factor for the socio-economic development of a country [84], which makes demographic forecasts highly important for policy planning [1].

\subsection{Public Finances}

A relevant policy area impacted by demographics is public finances. Beznoska and Hentze [85] use a combination of a population forecast and a microsimulation model to show that income tax revenue in Germany will decline significantly by 2035 as a result of demographic developments. The results show that the financial pressure on the public sector will intensify as government spending will increase, especially in social security and education. Kochskämper [86], for example, illustrates this increase in social security spending. Based on a population forecast, the study projects the increase in spending due to population aging in the statutory pension, statutory health, and social long-term care insurance up to 2035. The results show that a constant level of benefits in all three classes of insurance by 2035 will probably require a 35 percent higher overall per-capita expenditure compared to the current level. Population projections thus serve as an information basis for fiscal and social policy $[27,87]$. Comparable trends can be found in large parts of the EU and the Schengen area, which significantly limits the opportunities for immigration of qualified workers among Schengen countries. For example, the EU estimates a relative decline in its working-age population (defined as 15-64 year-olds) from $65.3 \%$ to $55.9 \%$ of the total population on average between 2016 and 2070, with a simultaneous increase in the very old (80 years and older) from $5.5 \%$ to $12.9 \%$ [88]. 


\subsection{Infrastructure}

Population projections are a valuable source of information for issues of infrastructure planning [8]. For instance, Hyndman and Fan [89] conduct a 10-year forecast of electricity demand in Australia, using a population forecast as an input variable. Future population development is a key determinant for the development of new plants and the alignment of existing plants. Knowledge of the probable development of the number of students and school graduates helps school demand planning in capacity planning [1,90], such as the creation of new jobs. Population forecasts provide information on the development of the number of pre-school-age children, school-age children, or university students [90]. Forecasts of the future population structure is also of high importance for long-term planning of health services, such as hospital and nursing home capacities [1,29] and the demand for nurses [29]. At the political level, the aging of society could shift the power structure, as the voting behavior of older people differs from that of younger people. In the future, senior citizens will represent a larger population group, and politics may therefore increasingly focus on this target group with measures and "election gifts" [1].

\subsection{Global Trends}

Population forecasts offer a valuable basis for planning at the global level as well. The rapid growth of the world population is leading to an increasing demand for food [91]. This development leads to new challenges because food production already causes major environmental problems today, which will become more acute in the future. Against this background, the connection between future population development and climate change is a central research topic and area of application of population forecasts [92]. Moreover, according to the current study results, the growing world population is causing an increase in the global volume of waste [93,94]. Therefore, population projections provide valuable information for economic cost evaluation of possible subvention programs, which aim at reducing garbage and wastefulness.

\section{Practical Issues in Population Forecasting}

Following the CCM, the demographic components are commonly projected based on administrative data [7]. In industrialized countries, births and deaths are normally certified by hospitals [95,96], which then forward this information to the statistical offices, which then offer the cumulated data to the public. While this information in these countries is basically very reliable $[95,97,98]$, the situation differs significantly for the case of international or internal migration. Migratory processes are difficult to monitor, especially within the EU $[3,19,97]$. Although migrants are obliged to deregister from their old place of residence and register at their new place of residence, the possibility to monitor the adherence to these rules is limited. Errors occurring in the migration data lead to massive errors in the population estimates as well $[7,35]$.

Another error in the population estimates originates from the census error [99]. Many users of official population data are not aware that the reported data are seldomly the actual population numbers but simply estimates originating from the latest census, which is a sample from the population and from which the population estimate is derived [100], in combination with the cohort-component update. The errors in the migration data then add over time, which can lead to large errors in the population data, if the time intervals between two adjacent census are long. For instance, in the case of Germany, the last census preceding the 2011 census took place in 1987 in West Germany and 1981 in East Germany. These extremely long intervals between the adjacent census in combination with the errors in migration, especially due to the reunification in 1990 and the fall of the Iron Curtain, led to large errors in the population estimates [97]. These circumstances accumulated to an overestimation of the population in Germany by approximately 1.3 million persons on 31 December 2010 [101,102], especially in the elderly population. 
Lastly, restructuring of countries led to errors as well. The EU, e.g., had several enlargements since the early 1990s [35]. The former Soviet Union and Yugoslavia separated into many smaller, independent countries since the early 1990s. By 1992, Bosnia and Herzegovina, Croatia, Macedonia, and Slovenia had declared independence from Yugoslavia. In 2006, Montenegro followed, while Kosovo became independent only in 2008. Therefore, consistent time series for these countries are difficult to retrieve, and especially older migration data are not always representative, as the barriers and regulations have changed for the countries witnessing one of the described structural changes [35].

The errors in the population and migration data make population forecasts vulnerable to errors, as the baseline data for migration forecast models are erroneous, and the data for the old-age population tends to be rather weak as well. For instance, if an emigration is not covered in the data, the respective person will theoretically be counted in the population data of the source country further. Once this person reaches a certain age, the error in the data caused by miscounting said person will weigh heavier, as the old-age population overall is not as strong in numbers as the younger population [7]. This then leads to quite a heavy bias in the mortality data as well for these age groups.

Another issue is associated with small-area population forecasting, which increasingly is becoming a focal point of demographic research [103-107]. The problems associated with international migration within the EU apply to internal migration as well to some point, as migration within a country is even more difficult to monitor than cross-border migration [108]. Moreover, time series data of migration are often inconsistent, since spatial definitions of regions or districts change more often than national borders. Another issue in small-area forecasting is the small numbers of observations for the demographic components for smaller districts, leading to large errors in the statistical estimates, similar to the earlier explained problems of old-age mortality estimates. Moreover, forecasts between the different hierarchies should be consistent, which is not always the case, i.e., the forecasts for federal states should accumulate to the same forecast as derived for the respective country or similarly, the district forecasts in one federal state supposedly accumulate to the forecast of the total federal state [62]. We will not go too deep into this, as this would exceed the scope of this contribution. For further reading on this topic, we suggest, e.g., [18,105,109].

Further issues are restrictions in the regional and local infrastructure alongside the demand in the housing markets. A forecasted population growth is usually based on the assumption that there are enough flats constructed or present to absorb the population influx. The same is assumed for public transportation, child care, hospitals, and other parts of the infrastructure. This might not be the case, as providing needed infrastructure is not necessarily possible in the time needed due to organizational or financial restrictions. For instance, the construction of new buildings takes time, which can lead to a delay in new housing structures needed for population growth $[79,110]$. Childcare opportunities could be a factor in interregional migration [111] or the decision to reproduce [4,112]. This not only might require new buildings but also new kindergarten teachers. Those need to be educated first, which takes at least three years of training and in more developed countries, the demand for kindergarten teachers is higher than the number of persons willing to follow this career path [113]. Even immigration from qualified workers in that field will not cover shortages short-term, as human capital needs time to adjust to labor markets abroad and maybe needs further education to be accepted by the target country. The same holds for jobs in the medical field, especially nurses [114-117]. Therefore, a small-area population forecast may not be simply derived from statistical models but also restricted by practical complications. Moreover, especially local population projections in some cases do not present a realistic estimation of the future course, but rather a target, which is set because of political agendas $[5,30]$. Local politics might set a projection more negative than the range of realistic developments to retrieve third party grants. On the other hand, the projections might turn out to be overoptimistic to symbolize growth to attract investments [118]. 


\section{Conclusions and Outlook}

Our contribution has shown the need for information on the future demographic structure generated by population projections as a quantitative basis for political and economic decisions. However, the results of forecasts should not be taken as an absolute truth [119], as statements about future developments are subject to uncertainty [7]. For example, it is not the objective of models to predict special unexpected shocks such as wars or crises but to extrapolate fundamental demographic trends [35]. In principle, deterministic and stochastic methods are available for operationalizing the forecast uncertainty. Both approaches have advantages and disadvantages; accordingly, there is no "one correct approach". However, we gave insight into the broad limitations associated with the common deterministic approaches. These have to be kept in mind when conducting projections based on these methods. In addition to the available data basis, the interest in knowledge or the area of application must be checked for a suitable method; a method should be efficient as well, following the classical principle of Occam's Razor [3].

A critical attitude is particularly necessary when applying the results of population projections and population forecasts in practice. Models or assumptions that use past developments as a basis do not necessarily have to remain valid in the future. At the regional level, for example, population growth does not depend exclusively on demographic trends but also on whether the available infrastructure will in principle enable growth. It remains to be seen, for example, whether a housing market under consideration will be able to translate the construction demand resulting from population growth into new housing in the future. Otherwise, cities will reach their limits [72]. Population projections and population forecasts thus contain implicit assumptions [7]. In the example, regions must be able to absorb the growing demand for housing. Besides, further challenges arise from a positive population development. For instance, childcare capacities must be created [1] and local public transport must adapt its infrastructure to a growing number of passengers [65].

In this respect, users of population projections and forecasts must always keep an eye on the latest developments. Projections serve as a basis for a multitude of questions and applications, which have only been highlighted in this paper. The literature on the methodological approach is also currently experiencing many new impulses. The challenges of demographic change require this discourse as well as up-to-date information and simulation results as a basis for planning.

Author Contributions: Conceptualization, all authors; methodology, P.V.; software, not applicable; validation, not applicable; formal analysis, not applicable; investigation, all authors; resources, not applicable; data curation, P.V.; writing-original draft preparation, all authors; writing-review and editing, P.V.; visualization, P.V.; supervision, P.D. and C.B.W.; project administration, P.V.; funding acquisition, not applicable. All authors have read and agreed to the published version of the manuscript.

Funding: This research received no external funding.

Acknowledgments: We appreciate the timely and helpful remarks by the three anonymous reviewers, which contributed to significant improvements to our contribution.

Conflicts of Interest: The authors declare no conflict of interest.

\section{References}

1. Bujard, M. Consequences of enduring low fertility-A German case study: Demographic projections and implications for different policy fields. Comp. Popul. Stud. 2015, 40, 131-164. [CrossRef]

2. Höhn, C.; Mai, R.; Micheel, F. Demographic Change in Germany. In Demographic Change in Germany. The Economic and Fiscal Consequences; Hamm, I., Seitz, H., Werding, M., Eds.; Springer: Berlin/Heidelberg, Germany, 2008; pp. 9-33.

3. Bijak, J. Forecasting International Migration in Europe. A Bayesian View; Springer Science+Business Media: Dordrecht, The Netherlands; Heidelberg, Germany; London, UK; New York, NY, USA, 2011.

4. Vanella, P.; Deschermeier, P. A Principal Component Simulation of Age-Specific Fertility-Impacts of Family and Social Policy on Reproductive Behavior in Germany. Popul. Rev. 2019, 58, 78-109. [CrossRef]

5. Rayer, S. Population Forecast Errors: A Primer for Planners. J. Plan. Educ. Res. 2008, 27, 417-430. [CrossRef] 
6. Box, G.E.P.; Jenkins, G.M.; Reinsel, G.C.; Ljung, G.M. Time Series Analysis: Forecasting and Control; Wiley: Hoboken, NJ, USA, 2016.

7. Vanella, P.; Deschermeier, P. A Probabilistic Cohort-Component Model for Population Forecasting-The Case of Germany. J. Popul. Ageing 2020. [CrossRef]

8. Smith, S.K. Tests of Forecast Accuracy and Bias for County Population Projections. J. Am. Stat. Assoc. 1987, 82, 991-1003. [CrossRef]

9. Keyfitz, N. On Future Population. J. Am. Stat. Assoc. 1972, 67, 347-363. [CrossRef]

10. Booth, H. Demographic forecasting: 1980 to 2005 in review. Int. J. Forecast. 2006, 22, 547-581. [CrossRef]

11. Bohk, C. Ein Probabilistisches Bevölkerungsprognosemodell. Entwicklung Und Anwendung Für Deutschland; VS Verlag Für Sozialwissenschaften: Wiesbaden, Germany, 2012.

12. Deschermeier, P. Population Development of the Rhine-Neckar Metropolitan Area: A Stochastic Population Forecast on the Basis of Functional Data Analysis. Comp. Popul. Stud. 2011, 36, 769-806. [CrossRef]

13. Pritchett, H.S. A Formula for Predicting the Population of the United States. Publ. Am. Stat. Assoc. 1891, 2, 278-286. [CrossRef]

14. Census Bureau of England and Wales. General Report; with Appendix of Tables. Available online: http://www.visionofbritain.org.uk/census/EW1861GEN/5 (accessed on 5 March 2019).

15. Cannan, E. The Probability of a Cessation of the Growth of Population in England and Wales During the Next Century. Econ. J. 1895, 5, 505. [CrossRef]

16. Whelpton, P.K. Population of the United States, 1925 to 1975. Am. J. Sociol. 1928, 34, 253-270. [CrossRef]

17. Fuchs, J.; Söhnlein, D.; Weber, B.; Weber, E. Stochastic Forecasting of Labor Supply and Population: An Integrated Model. Popul. Res. Policy Rev. 2018, 37, 33-58. [CrossRef] [PubMed]

18. Rogers, A.; Castro, L.J. Model Migration Schedules: RR-81-30; International Institute for Applied Systems Analysis: Laxenburg, Austria, 1981.

19. Strozza, S.; De Santis, G. Rapporto Sulla Popolazione: Le Molte Facce Della Presenza Straniera in Italia; il Mulino: Bologna, Italy, 2017.

20. Bozik, J.E.; Bell, W.R. Forecasting Age Specific Fertility Using Principal Components; Bureau of the Census, Statistical Research Division: Washington, DC, USA, 1987.

21. Bell, W.R.; Monsell, B.C. Using principal components in time series modeling and forecasting of age-specific mortality rates. In Proceedings of the Social Statistics Section; Association, A.S., Ed.; American Statistical Association: Alexandria, VA, USA, 1991; pp. 154-159.

22. Lee, R.D.; Carter, L.R. Modeling and forecasting U.S. mortality. J. Am. Stat. Assoc. 1992, 87, $659-671$. [CrossRef]

23. Hyndman, R.J.; Ullah, M.S. Robust forecasting of mortality and fertility rates: A functional data approach. Comput. Stat. Data Anal. 2007, 51, 4942-4956. [CrossRef]

24. Vanella, P. A principal component model for forecasting age- and sex-specific survival probabilities in Western Europe. Zeitschrift Für Die Gesamte Versicherungswissenschaft 2017, 106, 539-554. [CrossRef]

25. Wilke, C.B. German Pension Reform; Peter Lang Internationaler Verlag der Wissenschaften: Frankfurt, Germany, 2009.

26. Bowles, D. Finanzentwicklung Der Sozialen Pflegeversicherung. Modellrechnungen Unter Berücksichtigung Demografischer, Ökonomischer, Gesundheitlicher Und Sozialrechtlicher Rahmenbedingungen; Nomos Verlagsgesellschaft: Baden-Baden, Germany, 2015.

27. Deschermeier, P. Die Entwicklung der Bevölkerung Deutschlands bis 2030: Ein Methodenvergleich. IW Trends Vierteljahresschrift Zur Empirischen Wirtschaftsforschung 2015, 42, 97-111.

28. Keilman, N.; Dinh, Q.P.; Hetland, A. Why population forecasts should be probabilistic-Illustrated by the case of Norway. Demogr. Res. 2002, 6, 409-454. [CrossRef]

29. Vanella, P.; Heß, M.; Wilke, C.B. A probabilistic projection of beneficiaries of long-term care insurance in Germany by severity of disability. Qual. Quant. 2020, 54, 943-974. [CrossRef]

30. Soneji, S.; King, G. Statistical Security for Social Security. Demography 2012, 49, 1037-1060. [CrossRef]

31. Lee, R.D. Probabilistic Approaches to Population Forecasting. Popul. Dev. Rev. 1998, 24, 156-190. [CrossRef]

32. Chatfield, C.; Collins, A.J. Introduction to Multivariate Analysis; Chapman \& Hall: London, UK, 1980.

33. Mori, Y.; Kuroda, M.; Naomichi, M. Nonlinear Principal Component Analysis and Its Applications; Springer: Singapore, 2016. 
34. Vanella, P. Stochastic Forecasting of Demographic Components Based on Principal Components Analyses. Athens J. Sci. 2018, 5, 223-246. [CrossRef]

35. Vanella, P.; Deschermeier, P. A stochastic Forecasting Model of international Migration in Germany. In Familie-Bildung-Migration. Familienforschung Im Spannungsfeld Zwischen Wissenschaft, Politik Und Praxis. Tagungsband Zum 5. Europäischen Fachkongress Familienforschung; Kapella, O., Schneider, N.F., Rost, H., Eds.; Verlag Barbara Budrich: Opladen, Berlin, Germany; Toronto, ON, Canada, 2018; pp. 261-280.

36. Lynch, S.M. Introduction to Applied Bayesian Statistics and Estimation for Social Scientists; Springer Business+Media: New York, NY, USA, 2007.

37. Kruschke, J.K. Doing Bayesian Data Analysis. A Tutorial with R, JAGS and Stan; Academic Press: London, UK; San Diego, CA, USA; Waltham, MA, USA; Oxford, UK, 2015.

38. United Nations. World Population Prospects 2019: Highlights. Available online: https://population.un.org/ wpp/Publications/Files/WPP2019_Highlights.pdf (accessed on 25 June 2020).

39. Destatis. Bevölkerung Im Wandel. Annahmen Und Ergebnisse Der 14. Koordinierten Bevölkerungsvorausberechnung. Available online: https://www.destatis.de/DE/Presse/Pressekonferenzen/ 2019/Bevoelkerung/pressebroschuere-bevoelkerung.pdf?_blob=publicationFile (accessed on 25 June 2020).

40. Gløersen, E.; Drăgulin, M.; Hans, S.; Kaucic, J.; Schuh, B.; Keringer, F.; Celotti, P. The Impact of Demographic Change on European Regions; Publications Office of the European Union: Luxembourg, 2016.

41. United Nations. World Population Prospects 2019, Volume I: Comprehensive Tables (ST/ESA/SER.A/426). Available online: https://population.un.org/wpp/Publications/Files/WPP2019_Volume-I_ComprehensiveTables.pdf (accessed on 25 June 2020).

42. United Nations. World Population Prospects 2019, Volume II: Demographic Profiles (ST/ESA/SER.A/427). Available online: https:/population.un.org/wpp/Publications/Files/WPP2019_Volume-II-DemographicProfiles.pdf (accessed on 25 June 2020).

43. Raftery, A.E.; Alkema, L.; Gerland, P. Bayesian population projections for the United Nations. Stat. Sci. 2014, 29, 58-68. [CrossRef]

44. Raftery, A.E.; Chunn, J.L.; Gerland, P.; Ševčíková, H. Bayesian probabilistic projections of life expectancy for all countries. Demography 2013, 50, 777-801. [CrossRef] [PubMed]

45. Raftery, A.E.; Lalić, N.; Gerland, P. Joint probabilistic projection of female and male life expectancy. Demogr. Res. 2014, 30, 795-822. [CrossRef] [PubMed]

46. Alkema, L.; Raftery, A.E.; Gerland, P.; Clark, S.J.; Pelletier, F.; Büttner, T.; Heilig, G.K. Probabilistic projections of the Total fertility rate for all countries. Demography 2011, 48, 815-839. [CrossRef] [PubMed]

47. United Nations. World Population Prospects 2019: Methodology of the United Nations Population Estimates and Projections. Available online: https://population.un.org/wpp/Publications/Files/WPP2019_Methodology. pdf (accessed on 25 June 2020).

48. Lutz, W.; KC, S. Dimensions of global population projections: What do we know about future population trends and structures? Philos. Trans. R. Soc. B Boil. Sci. 2010, 365, 2779-2791. [CrossRef]

49. United Nations. How certain are the United Nations global population projections? Popul. Facts 2019, 2019, 1-4.

50. United Nations Population Division. World Population Prospects. Available online: https://population.un. org/wpp/Graphs/Probabilistic/900 (accessed on 25 June 2020).

51. Eurostat. TECHNICAL NOTE Methodology of the Eurostat Population Projections 2019-Based (EUROPOP2019). Available online: https://ec.europa.eu/eurostat/cache/metadata/Annexes/proj_esms_ an1.pdf (accessed on 26 June 2020).

52. Eurostat. Population Projections. Annex 22-Population Pyramids at Selected Years. Available online: https://ec.europa.eu/eurostat/cache/metadata/Annexes/proj_esms_an23.pdf (accessed on 26 June 2020).

53. Eurostat Database. Population Projections; Eurostat, Ed.; Eurostat: Luxembourg, 2020.

54. Destatis. Bevölkerungsvorausberechnungen. Available online: https:/www-genesis.destatis.de/genesis/ online?operation=statistic\&levelindex=0\&levelid=1593175898175\&code=12421 (accessed on 26 June 2020).

55. Billari, F.C.; Graziani, R.; Melilli, E. Stochastic population forecasts based on conditional expert opinions. J. R. Stat. Soc. Stat. Soc. 2012, 175, 491-511. [CrossRef]

56. Istat. Il Futuro Demografico del Paese. Previsioni Regionali Della Popolazione Residente Al 2065; Istat: Roma, Italy, 2017. 
57. Istat. Previsioni Della Popolazione-Anni 2018-2065. Available online: http://dati.istat.it/\# (accessed on 27 June 2020).

58. Schlömer, C.; Bucher, H.; Hoymann, J. Die Raumordnungsprognose 2035 nach dem Zensus. 2015. Available online: https://www.bbsr.bund.de/BBSR/DE/veroeffentlichungen/analysen-kompakt/2015/ AK052015.html (accessed on 26 June 2020).

59. Schlömer, C. Demografische Prognosen: Per Annahme in die Zukunft. Informationen Zur Raumentwicklung 2018, 2018, 4-9.

60. Destatis. Bevölkerungsentwicklung Deutschlands Bis Zum Jahr 2050: Ergebnisse Der 9. Koordinierten Bevölkerungsvorausberechnung; Destatis, Ed.; Destatis: Wiesbaden, Germany, 2000.

61. Pötzsch, O.; Rößger, F. Germany's Population by 2060: Results of the 13th Coordinated Population Projection; Destatis, Ed.; Destatis: Wiesbaden, Germany, 2015.

62. Deschermeier, P. Bevölkerungsentwicklung in den deutschen Bundesländern bis 2035 . IW Trends Vierteljahresschrift Zur Empirischen Wirtschaftsforschung 2017, 44, 63-80. [CrossRef]

63. Maier, T.; Zika, G.; Wolter, M.I.; Kalinowski, M.; Neuber-Pohl, C. Die Bevölkerung wächst—Engpässe bei fachlichen Tätigkeiten bleiben aber dennoch bestehen. Forschungs- Und Arbeitsergebnisse Aus Dem Bundesinstitut Für Berufsbildung 2016, 10, 10-20.

64. McNair, S.; Flynn, M.; Myerson, J.; Gheerawo, R.; Ramster, G. What Are the Supply (Workforce) and Demand (Product) Implications of an Ageing Society? 2012. Available online: https://www.bl.uk/collection-items/ what-are-the-supply-workforce-and-demand-product-implications-of-an-ageing-society (accessed on 26 June 2020).

65. Weidner, W.; Vanella, P.; Zuchandke, A. Die Entwicklung der Kfz-Zulassungen in Deutschland: Eine Prognose und Implikationen für die Kraftfahrtversicherung. Zeitschrift Für Die Gesamte Versicherungswissenschaft 2015, 104, 365-387. [CrossRef]

66. Meng, D.; Xu, G.; He, L.; Zhang, M.; Lin, D. What determines the preference for future living arrangements of middle-aged and older people in urban China? PLoS ONE 2017, 12, e0180764. [CrossRef] [PubMed]

67. Börsch-Supan, A.H. Gesamtwirtschaftliche Folgen des demographischen Wandels. Geographische Rundschau 2007, 59, 48-52.

68. Börsch-Supan, A.H. Saving and consumption patterns of the elderly. The German case. J. Popul. Econ. 1992, 5, 289-303. [CrossRef]

69. Börsch-Supan, A.H.; Wilke, C.B. Zur mittel-Und langfristigen Entwicklung der Erwerbstätigkeit in Deutschland. Zeitschrift Für ArbeitsmarktForschung 2009, 42, 29-48. [CrossRef]

70. Beaverstock, J.V. Migration: Skilled International Labor. Int. Encycl. Geogr. 2017, 2017. [CrossRef]

71. Buch, T.; Hamann, S.; Niebuhr, A. Wanderungsbilanzen deutscher Metropolen. Der Wettbewerb um kluge Köpfe nimmt zu. IAB-Kurzbericht 2010, 2010, 1-8.

72. Hämäläinen, K.; Böckerman, P. Regional Labor Market Dynamics, Housing, and Migration. J. Reg. Sci. 2004, 44, 543-568. [CrossRef]

73. Consoli, D.; Sánchez-Barrioluengo, M. Polarization and the growth of low-skill service jobs in Spanish local labor markets. J. Reg. Sci. 2018, 59, 145-162. [CrossRef]

74. Adam, B.; Göddecke-Stellmann, J.; Heidbrink, I. Metropolregionen als Forschungsgegenstand. Aktueller Stand, erste Ergebnisse und Perspektiven. Informationen Zur Raumentwicklung 2005, 2005, 417-430.

75. Eurostat. Statistics on Commuting Patterns at Regional Level. Available online: https://ec.europa.eu/eurostat/ statistics-explained/pdfscache/50943.pdf (accessed on 22 June 2020).

76. Deschermeier, P.; Henger, R.; Seipelt, B.; Voigtländer, M. Wohnungsmangel in den Städten, Leerstand auf dem Land. 2017. Available online: https://www.iwkoeln.de/fileadmin/publikationen/2017/342975/IWKurzbericht_44_2017_Wohnungsmangel.pdf (accessed on 26 June 2020).

77. Orton, K. Experts Predict What the 2020 Housing Market Will Bring. Available online: https://www. washingtonpost.com/business/2020/01/06/experts-predict-what-housing-market-will-bring/ (accessed on 25 June 2020).

78. Snook, R.; Fisher, T.; Durham, J. UK housing market outlook. In UK Economic Outlook; PricewaterhouseCoopers, Ed.; PricewaterhouseCoopers: London, UK, 2018.

79. Mulder, C.H. Population and housing: A two-sided relationship. Demogr. Res. 2006, 15, 401-412. [CrossRef] 
80. Grömling, M. Wachstumsalternativen: Politische Handlungsdividenden. In Perspektive 2035. Wirtschaftspolitik Für Wachstum Und Wohlstand in Der Alternden Gesellschaft; German Economic Institute, Ed.; German Economic Institute: Cologne, Germany, 2017; pp. 114-124.

81. Deschermeier, P. Einfluss der Zuwanderung auf die demografische Entwicklung in Deutschland. IW Trends Vierteljahresschrift Zur Empirischen Wirtschaftsforschung 2016, 43, 21-38.

82. Schäfer, H. Arbeitsmarkt: Arbeitsangebot und Arbeitsvolumen. In Perspektive 2035. Wirtschaftspolitik Für Wachstum Und Wohlstand in Der Alternden Gesellschaft; German Economic Institute, Ed.; German Economic Institute: Cologne, Germany, 2017; pp. 57-74.

83. Bardt, H.; Klös, H.-P. Perspektive 2035: Handlungsfelder für mehr Wohlstand. In Perspektive 2035. Wirtschaftspolitik Für Wachstum Und Wohlstand in Der Alternden Gesellschaft; German Economic Institute, Ed.; German Economic Institute: Cologne, Germany, 2017; pp. 127-142.

84. Bloom, D.E.; Kuhn, M.; Prettner, K. Africa's Prospects for Enjoying a Demographic Dividend. Nber Work. Pap. Ser. 2016. [CrossRef]

85. Beznoska, M.; Hentze, T. Steuern: Staatsfinanzen demografiesicher machen. In Perspektive 2035. Wirtschaftspolitik Für Wachstum Und Wohlstand in Der Alternden Gesellschaft; German Economic Institute, Ed.; German Economic Institute: Cologne, Germany, 2017; pp. 143-156.

86. Kochskämper, S. Sozialversicherungen: Nachhaltigkeit ohne neue Leistungsversprechen. In Perspektive 2035. Wirtschaftspolitik Für Wachstum Und Wohlstand in Der Alternden Gesellschaft; German Economic Institute, Ed.; German Economic Institute: Cologne, Germany, 2017; pp. 157-168.

87. Lee, R.D.; Tuljapurkar, S. Stochastic Forecasts for Social Security. In Frontiers in the Economics of Aging; Wise, D.A., Ed.; University of Chicago Press: Chicago, IL, USA, 1998.

88. European Union. The 2018 Ageing Report: Economic \& Budgetary Projections for the 29 EU Member States (2016-2070); Publications Office of the European Union: Luxembourg, 2018.

89. Hyndman, R.J.; Fan, S. Density Forecasting for Long-Term Peak Electricity Demand. IEEE Trans. Power Syst. 2010, 25, 1142-1153. [CrossRef]

90. Bomsdorf, E.; Babel, B.; Schmidt, R. Zur Entwicklung der Bevölkerung, der Anzahl der Schüler, der Studienanfänger und der Pflegebedürftigen: Stochastische Modellrechnungen für Deutschland bis 2050. Sozialer Fortschritt 2008, 57, 125-132. [CrossRef]

91. Food and Agriculture Organization of the United Nations. Global Forest Resources Assessment 2015. How Are the World's Forests Changing; Food and Agriculture Organization of the United Nations: Roma, Italy, 2016.

92. Lutz, W. How population growth relates to climate change. Proc. Natl. Acad. Sci. USA 2017, 114, 12103-12105. [CrossRef]

93. Kaza, S.; Yao, L.C.; Bhada-Tata, P.; Van Woerden, F. What a Waste 2.0: A Global Snapshot of Solid Waste Management to 2050; World Bank: Washington, DC, USA, 2018. [CrossRef]

94. World Economic Forum; Ellen MacArthur Foundation; McKinsey \& Company. The New Plastics Economy: Rethinking the Future of Plastics; Ellen MacArthur Foundation: Cowes, UK, 2016.

95. UNICEF Data and Analytics Section. Every Child's Birth Right: Inequities and Trends in Birth Registration; UNICEF: New York, NY, USA, 2013.

96. BinSaeed, A.A.; Al-Saadi, M.M.; AlJerian, K.A.; Al-Saleh, S.A.; Al-Hussein, M.A.; Al-Majid, K.S.; Al-Sani, Z.S.; Al-Rabeeah, K.A.; Arab, K.A.; Al-Sheikh, K.A.; et al. Assessment of the accuracy of death certification at two referral hospitals. J. Fam. Community Med. 2008, 15, 43-50.

97. Scholz, R.; Jdanov, D.; Kibele, E.; Grigoriev, P.; Klüsener, S. About Mortality Data for Germany. Available online: https://www.mortality.org/hmd/DEUTNP/InputDB/DEUTNPcom.pdf (accessed on 15 August 2020).

98. Glei, D.A.; Borges, G.; Riffe, T.; Andreeva, M.; Menares, F. About Mortality Data for Italy. Available online: https://www.mortality.org/hmd/ITA/InputDB/ITAcom.pdf (accessed on 15 August 2020).

99. Price, D.O. Examination of Two Sources of Error in the Estimation of Net Internal Migration. J. Am. Stat. Assoc. 2012, 50, 689-700. [CrossRef]

100. Statistische Ämter Des Bundes Und Der Länder. Wie Funktioniert Der Zensus? Die Ermittlung Der Einwohnerzahl Im Zensus 2021. Available online: https://www.zensus2021.de/DE/Wie-funktioniert-derZensus/ermittlung-einwohnerzahl-registergestuetzt.html?nn=352854 (accessed on 15 August 2020).

101. GENESIS-Online. Bevölkerung: Deutschland, Stichtag. Available online: https://www-genesis.destatis.de/ (accessed on 15 August 2020). 
102. Human Mortality Database. Germany, Population Size (Abridged). Available online: https://www.mortality. org/hmd/DEUTNP/STATS/Population.txt (accessed on 15 August 2020).

103. Chi, G.; Marcouiller, D.W. Isolating the Effect of Natural Amenities on Population Change at the Local Level. Reg. Stud. 2011, 45, 491-505. [CrossRef]

104. Chi, G.; Voss, P.R. Small-area population forecasting: Borrowing strength across space and time. Popul. Space Place 2011, 17, 505-520. [CrossRef]

105. Wilson, T.; Brokensha, H.; Rowe, F.; Simpson, L. Insights from the Evaluation of Past Local Area Population Forecasts. Popul. Res. Policy Rev. 2018, 37, 137-155. [CrossRef]

106. Wilson, T. New Evaluations of Simple Models for Small Area Population Forecasts. Popul. Space Place 2014, 21, 335-353. [CrossRef]

107. Kooiman, N.; Latten, J.; Bontje, M. Human Capital Migration: A Longitudinal Perspective. Tijdschrift Voor Economische En Sociale Geografie 2018, 109, 644-660. [CrossRef]

108. UNESCO. Internal migration. In Global Education Monitoring Report 2019. Migration, Displacement and Education: Building Bridges, not Walls; UNESCO, Ed.; UNESCO Publishing: Paris, France, 2019; pp. 11-31.

109. Rogers, A.; Little, J.; Raymer, J. The Indirect Estimation of Migration; Springer Science+Business Media: Dordrecht, The Netherlands; Heidelberg, Germany; London, UK; New York, NY, USA, 2010.

110. Testa, M.R.; Bolano, D. From intentions to births: Gendered paths of realization in a multi-dimensional life course perspective. In Familie-Bildung-Migration. Familienforschung Im Spannungsfeld Zwischen Wissenschaft, Politik Und Praxis. Tagungsband Zum 5. Europäischen Fachkongress Familienforschung; Kapella, O., Schneider, N.F., Rost, H., Eds.; Verlag Barbara Budrich: Opladen, Berlin, Germany; Toronto, ON, Canada, 2018; pp. 105-123.

111. Green, A.E.; Canny, A. Geographical Mobility: Family Impacts; Warwick University, Ed.; The Policy Press: Bristol, UK, 2003.

112. Bujard, M. Wirkungen von Familienpolitik auf die Geburtenentwicklung. In Handbuch Bevölkerungssoziologie; Niephaus, Y., Kreyenfeld, M., Sackmann, R., Eds.; Springer Fachmedien: Wiesbaden, Germany, 2016; pp. 619-646.

113. Warnecke, T. In Deutschland Fehlen Hunderttausende Erzieher. Available online: https://www.tagesspiegel. de/wissen/nationaler-bildungsbericht-in-deutschland-fehlen-hunderttausende-erzieher/22719474.html (accessed on 18 August 2020).

114. Brücker, H.; Hauptmann, A.; Vallizadeh, E. Flüchtlinge und andere Migranten am deutschen Arbeitsmarkt: Der Stand im September 2015. Aktuelle Berichte 2015, 2015, 1-15.

115. Lieb, S. Fachkräftemangel in der Pflege: Neue Gesetze und alte Probleme. Clavis 2018, 2018, 8-10.

116. Thießen, E. Bestandsaufnahme und Tipps für Unternehmen: Arbeitsmarktintegration von Geflüchteten am Beispiel der Pfege. Clavis 2018, 2018, 12-13.

117. Kühner, A. Qualifizierung: Ausländische Ärzte brauchen viel Geduld. Clavis 2018, 2018, 14-15.

118. Wachs, M. When Planners Lie with Numbers. J. Am. Plan. Assoc. 1989, 55, 476-479.

119. Bräuninger, M.; Teuber, M.-O. Bevölkerungsprognosen und ihre Interpretation. Wirtschaftsdienst 2016, 2016, 444-446. [CrossRef]

(C) 2020 by the authors. Licensee MDPI, Basel, Switzerland. This article is an open access article distributed under the terms and conditions of the Creative Commons Attribution (CC BY) license (http://creativecommons.org/licenses/by/4.0/). 